\title{
Neurological disorders and adult coeliac disease'
}

\author{
JOHN S. MORRIS, A. B. AJDUKIEWICZ, AND A. E. READ \\ From the Department of Medicine, Bristol Royal Infirmary
}

SUMMARY An investigation into the incidence of neurological disorder in 30 patients with adult coeliac disease has shown that three patients had severe depression, two had epileptiform convulsions, and one patient only had signs of involvement of the peripheral nervous system. Motor nerve conduction velocity was low in only one patient. When the nerve conduction velocities of the group on a gluten-free diet were compared with the group who were not on a gluten-free diet, there was no statistically significant difference. Similarly, nerve conduction velocities in patients with a low serum pyridoxal level were not significantly different from those with normal serum pyridoxal levels.

Measurements of the serum level of pyridoxal in 30 patients confirmed that pyridoxine $\stackrel{\odot}{\varnothing}$ deficiency occurs in adult coeliac disease and that the restriction of gluten from the diet $\overline{\vec{\partial}}$ appeared to affect pyridoxal levels favourably.

Since the introduction of peroral jejunal biopsy has made a definitive diagnosis of adult coeliac disease possible (Fone, Cooke, Meynell, Brewer, Harris, and Cox, 1960), several authors have commented on the relationship between the condition and neurological disease. The largest reported series is that of Cooke and Smith (1966), who described 16 cases of adult coeliac disease each with a neurological disorder. Peripheral neuropathy in association with adult coeliac disease was seen in a patient described by Binder, Solitare, and Spiro (1967), whilst Hall (1968) reported a patient with the combination of a proximal myopathy and adult coeliac disease.

The nature of the relationship is unknown. In the series reported by Cooke and Smith (1966), some of the patients appeared to respond to parenteral pyridoxine therapy. These authors commented on the similarity between the neurological disorder of adult coeliac disease and that seen in states of disturbed pyridoxine metabolism, and suggested that a similar disorder of pyridoxine metabolism might be pertinent to the

Received for publication 15 December 1969.

'Based on a paper read to the British Society of Gastroenterology on 8 November 1969. occurrence of neurological abnormality in adult coeliac disease.

The present investigation was designed to estimate the frequency with which neurological abnormalities, both clinical and latent, occur in adult coeliac disease and to relate these to serum levels of pyridoxine.

\section{Patients and Methods}

Thirty patients with adult coeliac disease were investigated. Nineteen of the patients were female.

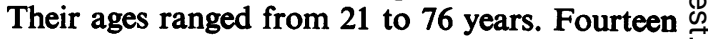
of the patients (10 female) had been on a gluten- $T$ free diet for six months to 15 years (mean 4.7 years); 10 patients (five female) had been on a $\mathbb{D}$ low fat diet with dietary supplements, usually of $\frac{\mathbb{D}}{\otimes}$ calcium, vitamin $D$, and folic acid, for one to eight $\frac{\circ}{\sigma}$ years (mean 4.6 years), and six patients (three female) were undergoing investigation before $ᄋ$ the start of treatment. In 28 patients the diagnosis had been confirmed by the presence of subtotal $\overline{0}$ villous atrophy in a peroral biopsy of the jejunal $\rightleftharpoons$ mucosa; in the two remaining patients the 
diagnosis had been suggested clinically and substantiated by a response to dietary gluten withdrawal. In the treated patients the response to treatment had been judged to be satisfactory although one female patient had required corticosteroid therapy in addition to gluten withdrawal from the diet. One female patient had diabetes which was difficult to control.

All patients underwent a complete neurological examination. Motor nerve conduction velocity was measured in the lateral popliteal nerve to the extensor digitorum brevis (Thomas, Sears, and Gilliatt, 1959). Normal range is 35.6-63.5 $\mathrm{m} /$ second). Action potentials were measured in the lateral popliteal nerve in the manner described by Gilliatt, Goodman, and Willison (1961). (Normal range is 2.0-15.5 $\mu \mathrm{v}$.)

Pyridoxine status was measured by estimating serum levels of pyridoxal following the hydrolysis of pyridoxal phosphate, the principal coenzyme form of vitamin $\mathbf{B}_{6}$ (Anderson, Peart, and Fulford Jones, 1969). The normal range alters with age. Serum levels of vitamin $B_{12}$ were measured by a modification of the method of Anderson (1964), normal $>120 \mu \mu \mathrm{g} / \mathrm{ml}$; serum folate levels were measured by a modification of the method of Chanarin and Berry (1964), normal range 4-12 $\mathrm{ng} / \mathrm{ml}$; serum calcium estimations were measured by the method of Gitelman (1967), normal range $9 \cdot 2-10 \cdot 7 \mathrm{mg} \%$. Haemoglobin levels were measured in all patients.

\section{Results}

\section{CLINICAL FINDINGS}

Three of the patients had severe depression, requiring psychiatric supervision. Two patients had experienced transient attacks of loss of consciousness of an epileptiform type. In one patient the attacks took the form of nocturnal myoclonus, whilst in the other the attacks consisted of generalized convulsions, one of which was followed by a transient hemiparesis. Paraesthesiae were complained of by nine $(30 \%)$ of the patients. Physical signs were seen in only one patient and consisted of muscle wasting, loss of reflexes, and mild sensory impairment.

\section{NERVE CONDUCTION STUDIES}

Motor nerve conduction velocity in the lateral popliteal nerve was measured in 26 of the 30 patients and was within the normal range in all but one. In one patient previous injury prevented the use of the lateral popliteal nerve but the motor nerve conduction velocity in the medial popliteal nerve to the flexor hallucis brevis was within the normal range. In the three remaining patients, although motor nerve conduction velocity could not be measured, the action

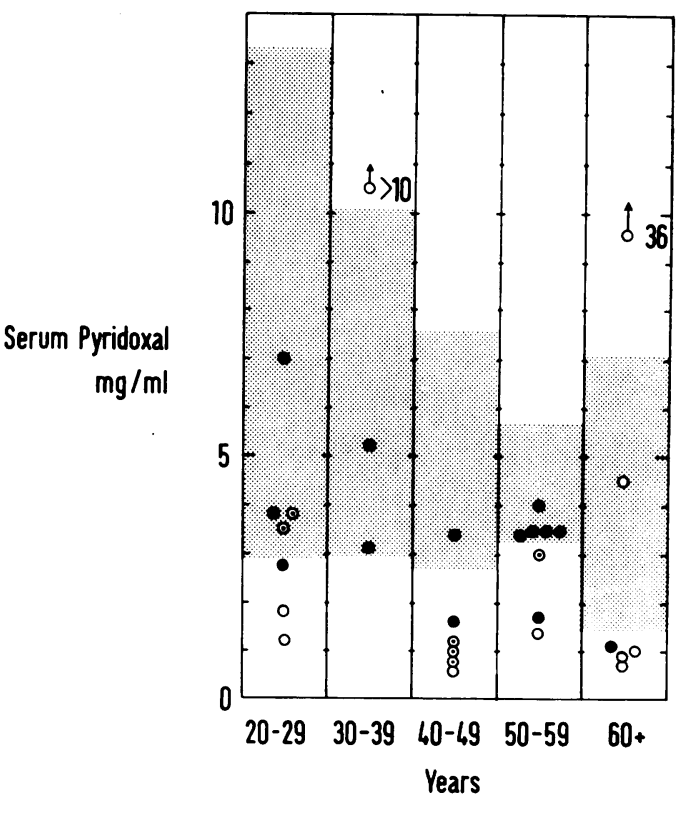

- gluten free diet
- no gluten restriction
- pre-treatment group

Fig. 1 Levels of serum pyridoxal in 30 patients with adult coeliac disease. The shaded areas represent the normal range in the different age groups.

potentials measured in the lateral popliteal nerve were normal.

\section{SERUM PYRIDOXAL LEVELS}

Fifteen patients had low serum levels of pyridoxal (Figure 1). Only four of the 14 patients on a gluten-free diet had levels outside the normal range compared with seven of the 10 patients on a low fat diet.

\section{OTHER FINDINGS}

Anaemia occurred in seven patients, of whom three were in the pretreatment group. Serum levels of vitamin $B_{12}$ were low in only two patients, each of whom was over 70 years of age. Serum calcium levels were lower in the patients on a gluten-free diet (mean $9.3 \mathrm{mg} \%$ ) compared with those patients on a low fat diet with additional calcium and vitamin D therapy (mean $9.6 \mathrm{mg} \%$ ). This difference was not statistically significant.

The relationship of all these findings to the neurological findings is given in Tables I, II, and III.

Serum levels of pyridoxal were within the normal range in all three patients with depression. Of the two patients with epileptiform convulsions, one had a low serum pyridoxal level at the time 
Neurological disorders and adult coeliac disease

\begin{tabular}{|c|c|c|c|c|c|c|c|c|}
\hline Patient & Age & Sex & $\begin{array}{l}\text { Duration of } \\
\text { Treatment }\end{array}$ & Clinical Features & $\begin{array}{l}\text { Motor Nerve } \\
\text { Conduction } \\
\text { Velocity }(\mathrm{m} / \mathrm{sec})^{1}\end{array}$ & $\begin{array}{l}\text { Action } \\
\text { Potentials }(\mu v)\end{array}$ & $\begin{array}{l}\text { Serum } \\
\text { Pyridoxal } \\
(\mathrm{ng} / \mathrm{ml})\end{array}$ & $\begin{array}{l}\text { Serum } \\
\text { Calcium } \\
(\mathrm{mg} / 100 \mathrm{ml})\end{array}$ \\
\hline 1 & 21 & $\mathbf{F}$ & 15 years & Paraesthesiae & 60 & - & $7 \cdot 0$ & $9 \cdot 3$ \\
\hline 2 & 29 & $\mathbf{F}$ & 7 years & Paraesthesiae & 38 & - & $2 \cdot 8(\downarrow)^{2}$ & $8 \cdot 4$ \\
\hline 3 & 29 & $\mathbf{F}$ & 9 years & - & - & 12 & $3 \cdot 7$ & $10 \cdot 0$ \\
\hline 4 & 31 & $\mathbf{F}$ & 1 year & Depression, paraesthesiae & 55 & - & $3 \cdot 1$ & 8.9 \\
\hline 5 & 30 & $\mathbf{F}$ & $1 \frac{1}{2}$ years & Depression & 38 & 10 & $5 \cdot 2$ & $9 \cdot 3$ \\
\hline 6 & 48 & $\mathbf{F}$ & 1 year & - & 40 & - & $3 \cdot 4$ & $9 \cdot 4$ \\
\hline 7 & 48 & $\mathbf{F}$ & $1 \frac{1}{2}$ years & - & 60 & 12 & $1.6(\downarrow)$ & $9 \cdot 1$ \\
\hline 8 & 52 & $\mathbf{M}$ & 6 years & - & 38 & - & $3 \cdot 4$ & 10.4 \\
\hline 9 & 54 & $\mathbf{F}$ & 11 months & Paraesthesiae & 58 & 10 & $4 \cdot 0$ & 9.6 \\
\hline 10 & 52 & $\mathbf{F}$ & 9 years & 'Fits' & 43 & 20 & $1 \cdot 7(\downarrow)$ & $9 \cdot 1$ \\
\hline 11 & 53 & $\mathbf{M}$ & 7 years & - & 50 & - & $3 \cdot 5$ & $10 \cdot 2$ \\
\hline 12 & 51 & $\mathbf{M}$ & $\frac{1}{2}$ year & Paraesthesiae & 52 & 5 & $3 \cdot 5$ & $9 \cdot 8$ \\
\hline 13 & 52 & $\mathbf{M}$ & 5 years & - & $47^{1}$ & - & $3 \cdot 5$ & $9 \cdot 1$ \\
\hline 14 & 64 & $\mathbf{F}$ & 1 year & - & 45 & - & $1 \cdot 1(\downarrow)$ & $8 \cdot 1$ \\
\hline
\end{tabular}

Table I Patients on a gluten-free diet

\begin{tabular}{|c|c|c|c|c|c|c|c|c|}
\hline Patient & Age & $\operatorname{Sex}$ & $\begin{array}{l}\text { Duration of } \\
\text { Treatment } \\
\text { (years) }\end{array}$ & Clinical Features & $\begin{array}{l}\text { Motor Nerve } \\
\text { Conduction } \\
\text { Velocity }(\mathrm{m} / \mathrm{sec})^{1}\end{array}$ & $\begin{array}{l}\text { Action } \\
\text { Potentials }(\mu v)\end{array}$ & $\begin{array}{l}\text { Serum } \\
\text { Pyridoxal } \\
(n g / m l)\end{array}$ & $\begin{array}{l}\text { Serum } \\
\text { Calcium } \\
(\mathrm{mg} / 100 \mathrm{ml})\end{array}$ \\
\hline 15 & 22 & $\mathbf{F}$ & 12 & - & 一 & 12 & $1 \cdot 8(\downarrow)^{2}$ & $9 \cdot 3$ \\
\hline 16 & 26 & $\mathbf{M}$ & 7 & - & 43 & - & $1 \cdot 2(\downarrow)$ & $9 \cdot 4$ \\
\hline 17 & 35 & $\mathbf{M}$ & 8 & Paraesthesiae & 53 & 12 & $>10$ & $9 \cdot 5$ \\
\hline 18 & 43 & $\mathbf{F}$ & 7 & - & - & 12 & $0.6(\downarrow)$ & $10 \cdot 5$ \\
\hline 19 & 53 & $\mathbf{F}$ & 5 & - & 45 & 10 & $1.4(\downarrow)$ & $10 \cdot 4$ \\
\hline 20 & 62 & $\mathbf{M}$ & 3 & 'Fits' & 49 & - & 36 & $9 \cdot 3$ \\
\hline 21 & 62 & $\mathbf{M}$ & 1 & - & 34 & - & $4 \cdot 5$ & $10 \cdot 1$ \\
\hline 22 & 64 & $\mathbf{F}$ & 3 & - & 44 & - & $0.9(\downarrow)$ & $9 \cdot 6$ \\
\hline 23 & 76 & $\mathbf{F}$ & 5 & - & 50 & $7 \cdot 5$ & $1 \cdot 0(\downarrow)$ & $9 \cdot 5$ \\
\hline 24 & 76 & $\mathbf{M}$ & 6 & - & 50 & 1 & $0.7(\downarrow)$ & $8 \cdot 4$ \\
\hline
\end{tabular}

Table II Patients with no dietary gluten restriction

\begin{tabular}{|c|c|c|c|c|c|c|c|}
\hline Patient & Age & $\operatorname{Sex}$ & Clinical Features & $\begin{array}{l}\text { Motor Nerve } \\
\text { Conduction } \\
\text { Velocity }(\mathrm{m} / \mathrm{sec})^{1}\end{array}$ & $\begin{array}{l}\text { Action } \\
\text { Potentials }(\mu v)\end{array}$ & $\begin{array}{l}\text { Serum } \\
\text { Pyridoxal } \\
(\mathrm{ng} / \mathrm{ml})\end{array}$ & $\begin{array}{l}\text { Serum } \\
\text { Calcium } \\
(\mathrm{mg} / 100 \mathrm{ml})\end{array}$ \\
\hline 25 & 28 & $\mathbf{F}$ & Depression & 60 & - & $3 \cdot 5$ & - \\
\hline 26 & 21 & $\mathbf{M}$ & $\begin{array}{l}\text { Paraesthesiae, weakness, wasting, sensory } \\
\text { impairment, reflex loss }\end{array}$ & 60 & 6 & $3 \cdot 8$ & $9 \cdot 1$ \\
\hline 27 & 42 & $\mathbf{F}$ & Paraesthesiae & 56 & - & $1 \cdot 2(\downarrow)^{2}$ & $9 \cdot 5$ \\
\hline 28 & 41 & $\mathbf{M}$ & - & 39 & - & $1 \cdot 0(\downarrow)$ & $8 \cdot 7$ \\
\hline 29 & 48 & $\mathbf{F}$ & - & 54 & 10 & $0.9(\downarrow)$ & $8 \cdot 7$ \\
\hline 30 & 52 & $\mathbf{F}$ & Paraesthesiae & 45 & 5 & $3 \cdot 0(\downarrow)$ & $8 \cdot 1$ \\
\hline
\end{tabular}

Table III Patients undergoing investigation

${ }^{1}$ Measured in the medial popliteal nerve to the flexor hallucis brevis.

${ }^{2}$ Levels below the normal range.

of his attacks. He has been treated with phenytoin sodium and pyridoxine and has had no further attacks. In the other patient the serum pyridoxal was not measured at the time of the attacks. Motor nerve conduction velocity was not significantly different in the patients with low serum levels of pyridoxal compared with those with normal levels of serum pyridoxal ${ }^{\mathbf{1}}$ (Fig. 2). Similarly, there was no difference when the motor nerve conduction velocity was compared in the group on a gluten-free diet with those patients who were not on a gluten-free $\operatorname{diet}^{1}$ (Fig. 3).

The mean serum calcium level was lower in the group with paraesthesia $(9 \cdot 1 \mathrm{mg} \%)$ compared with the group with no paraesthesia (mean $9.5 \mathrm{mg} \%$ ) but this difference was not statistically significant.

${ }^{1}$ Using the Wilcoxon-White rank sum test.

\section{Discussion}

Neurological complications of adult coeliac $N$ disease are rarely reported in the literature. N Cooke, Fone, Cox, Meynell, and Gaddie (1963) reviewed 50 patients with adult coeliac disease

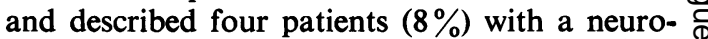
logical disorder. Subsequently, Cooke and Smith $\stackrel{?}{\cdot}$ (1966) described 16 patients with a neurological disorder and well documented adult coeliac disease.

\section{DEPRESSION}

Three patients in this series had severe depression. Other examples of psychiatric disorder occurring in coeliac disease have appeared in the literature. Cooke, Peeney, and Hawkins (1953), 


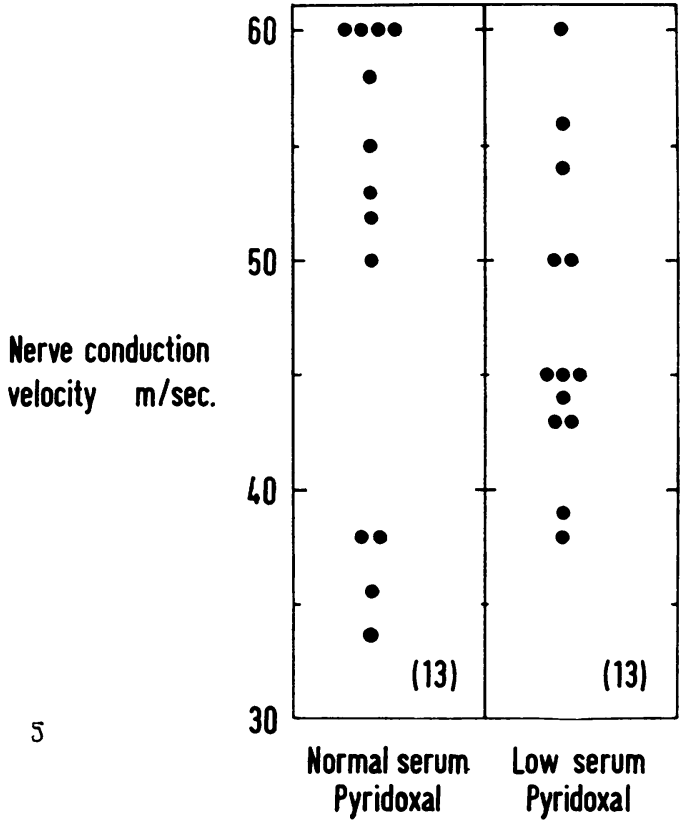

Fig. 2 Serum pyridoxal and nerve conduction velocity.

in their review of 100 patients with idiopathic steatorrhoea, described one patient with depression and a further patient with severe involutional melancholia. Benson, Kowlessar, and Sleisenger (1964) described a patient with a psychoneurotic reaction associated with depression in their review of 32 patients with adult coeliac disease. Daynes (1956) was so impressed with personality changes in children with coeliac disease that he proposed a pre-coeliac syndrome. The symptoms of this syndrome, which included irritability, listlessness, and naughtiness, responded dramatically to gluten withdrawal from the diet. Sheldon (1959) said that in his experience psychological disturbance characterized by depression was a prominent feature of childhood coeliac disease.

Whether there is a true increase in the incidence of depressive disorders in adult coeliac disease is, however, difficult to decide. Watts (1966) estimated that $15 \%$ of the home population have depressive disorders and do not consult a doctor, only $\mathbf{0} \cdot 2 \%$ coming under the care of a psychiatrist. A $10 \%$ incidence of psychiatric disorder in a group of patients attending hospital is, therefore, not surprising.

Additional evidence against a causal relationship between adult coeliac disease and depression was presented by Goldberg (1968), who found that the prevalence of psychiatric illness was broadly comparable in each of three groups of patients with coeliac syndrome, Crohn's disease, and alactasia. He further suggested that patients

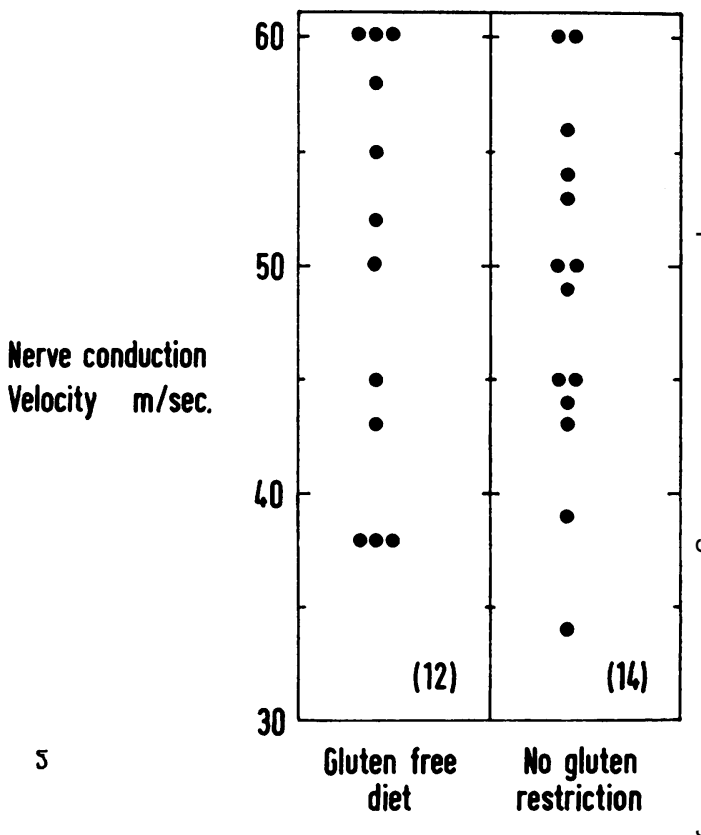

Fig. 3 Dietary gluten and nerve conduction velocity.

with psychiatric disorders overrepresent themselves in an outpatient department by being more likely to attend frequently.

PERIODS OF LOSS OF CONSCIOUSNESS

The general incidence of epileptiform attacks in the population is $0.5 \%$ (Report by the Research Committee of the College of General Practitioners, 1960). Therefore, although the figures are small, the finding of two patients with epileptiform attacks in a group of 30 patients may be significant. Cooke and Smith (1966) mention five patients with unexplained attacks of unconsciousness in their group of 16 patients with neurological disorders associated with adult $\sigma$ coeliac disease. Daynes (1956) found that $25 \%$ N of his children with the 'pre-coeliac syndrome' had attacks resembling petit mal.

Why patients with adult coeliac disease should get such attacks is not known. There is evidence

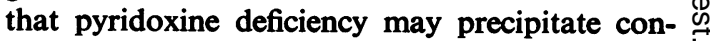
vulsions. Snyderman, Carretero, and Holt 7 (1953) gave pyridoxine-deficient diets to two mentally retarded children as a therapeutic measure. On the 76th day of this treatment one $\mathbb{\nabla}$ child developed convulsions which promptly responded to pyridoxine. Coursin (1954) reviewed 50 children with convulsions all of whom had been on a liquid formula diet with vitamin supplements which did not include pyridoxine. The convulsions responded promptly to the reintroduction of pyridoxine. The present evidence 
is not sufficient to ascribe a causal relationship to pyridoxine deficiency in the epileptiform attacks of adult coeliac disease.

\section{PARAESTHESIAE}

Paraesthesiae are not uncommon symptoms in patients with adult coeliac disease, especially at presentation. Benson et al (1964) found that 33\% of their patients with adult coeliac disease had paraesthesiae and this corresponds with an incidence of $30 \%$ in the present series. Spencer (1957) considered that anaemia was the cause of the paraesthesiae seen in the malabsorption syndrome. This was certainly not the cause in the present series. Green and Wollaeger (1960) attributed the paraesthesiae which they found in $28 \%$ of their patients with sprue to hypocalcaemia. In this series the mean level of serum calcium was lower in those patients with paraesthesia compared with those without, but the difference was not statistically significant.

\section{PERIPHERAL NEUROPATHY}

Reports of involvement of the peripheral nervous system in adult coeliac disease are rare. Farmer and Richards (1964) described a patient with a peripheral neuropathy in whom a biopsy of the jejunal mucosa showed changes typical of 'nontropical sprue'. The largest series of patients with involvement of the peripheral nerves in association with adult coeliac disease is that described by Cooke and Smith (1966). The symptoms in these patients occurred more commonly in the legs than arms and consisted of pain, weakness, and unsteadiness of gait. Sensory ataxia occurred eventually in most of the patients. Histological changes were seen in nine patients examined at necropsy and included lesions in the cerebral cortex, basal ganglia, brainstem, spinal cord, and sensory ganglia. Nerve and muscle biopsies performed in 10 of the patients revealed changes on both light and electron microscopy (Cooke, Johnson, and Woolf, 1966). Finally Binder et al (1967) described one further patient with peripheral neuropathy and histologically proven adult coeliac disease.

In the present series of patients with adult coeliac disease significant involvement of the peripheral nervous system was not seen. Further, nerve conduction studies failed to detect latent neurological abnormality in the legs-the situation where it is said to occur earliest and to be most severe (Cooke and Smith, 1966). Similar studies in diabetics and patients with impairment of renal function have revealed evidence of peripheral nerve involvement in the absence of clinical signs (Gregerson, 1964; Preswick and Jeremy, 1964).

The cause of the involvement of the peripheral nervous system seen in patients with adult coeliac disease is not known. Cooke and Smith (1966) found no relationship between the neurological abnormalities they described and lowered serum levels of folate or vitamin $B_{12}$; nor did dietary gluten restriction appear to be important.

Cooke and Smith (1966) found that five of their patients with peripheral nerve involvement $\underset{\vec{F}}{\vec{*}}$ made an almost complete recovery when given-? large amounts of parenteral vitamins, including $\frac{\subseteq}{\partial}$ pyridoxine. Peripheral neuropathy may occur in $\overline{\bar{m}}$ association with disturbed pyridoxine meta- $\bar{\phi}$ bolism, for example, the neuropathy which $\cong$ occurs during treatment with isoniazid and ${ }^{\infty}$ hydrallazine (Biehl and Vilter, 1954; Raskin and $\vec{O}$ Fishman, 1965), so that it is theoretically possible $\overrightarrow{-}$ that pyridoxine deficiency is a cause of the ${ }_{\sigma}$ peripheral neuropathy seen in adult coeliace disease. In the present series, however, there was no significant difference between the motor nerve conduction velocities in those patients with $a$ ir low serum pyridoxal level compared with those with normal serum pyridoxal levels.

We are grateful to $\mathrm{Dr} B$. Anderson and her colleagues at St Bartholomew's Hospital for help with the measurement of serum levels of pyridoxal many of which were performed in her department, and for allowing us to quote her normal ranges. We are also grateful to Dr G. Wakefield, consultant neurologist, Royal United Hospitals, Bath, who performed the nerve conduction $\bigcirc$ studies. We are indebted to Mrs S. Rollitt for $\overrightarrow{\vec{\partial}}$ much technical help.

References

Anderson, B. B. (1964). Investigations into the Euglena method for the assay of vitamin $B_{12}$ in the serum. J. clin. Path., 17, 14-26.

Anderson, B. B., Peart, M. D., and Fulford-Jones, C. E. (1969). 을 The measurement of serum pyridoxal by a microbiological assay using lactobacillus casei. (In press.)

Benson, G. D., Kowlessar, O. D., and Sleisenger, M. H. (1964). 윽 Adult celiac disease with emphasis upon response to the gluten-free diet. Medicine (Baltimore), 43, 1-40.

Biehl, J. P., and Vilter, R. W. (1954). Effect of isoniazid on vitamin $B_{\text {a }}$ metabolism: its possible significance in producing $\mathrm{N}$ isoniazid neuritis. Proc. Soc. exp. Biol. (N.Y.), 85, 389-392.

Binder, H. J., Solitare, G. B., and Spiro, H. M. (1967). Neuro- N muscular disease in patients with steathorrhoea. Gut, 8, $605-611$.

Chanarin, I., and Berry, V. (1964). Estimation of serum L. casei $\sigma$ activity. J. clin. Path, 17, 111-113.

Cooke, W. T., Fone, D. J., Cox, E. V., Meynell, M. J., and Gaddie, R. (1963). Adult coeliac disease. Gut, 4, 279-291.

Cooke, W. T., Johnson, A. G., and Woolf, A. L. (1966). Vital \& staining and electron microscopy of the intramuscular: nerve endings in the neuropathy of adult coeliac disease. Brain, 89, 663-682.

Cooke, W. T., Peeney, A. L. P., and Hawkins, C. F. (1953). (D)

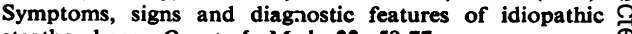
steathorrhoea. Quart. J. Med., 22, 59-77.

Cooke, W. T., and Smith, W. T. (1966). Neurological disorders associated with adult coeliac disease. Brain, 89, 683-722.

Coursin, D. B. (1954). Convulsive seizures in infants with a pyridoxine-deficient diet. J. Amer. med. Ass., 154, 406-408. 응

Daynes, G. (1956). Bread and tears-Naughtiness, depression and fits due to wheat sensitivity. Proc. roy. Soc. Med., 49, 391-394.

Farmer, R. G., and Richards, N. G. (1964). Malabsorption syndromes and peripheral neuropathy. Cleveland Clin. Quart., 31, 163-168. 
Fone, D. J., Cooke, W. T., Meynell, M. J., Brewer, D. B., Harris, E. L., and Cox, E. V. (1960). Jejunal biopsy in adult coeliac disease and allied disorders. Lancet, 1, 933-938.

Gilliatt, R. W., Goodman, H. V., and Willison, R. G. (1961). The recording of lateral popliteal nerve action potentials in man. J. Neurol. Neurosurg. Psychiat., 24, 305-318.

Gitelman, H. J. (1967). An improved automated procedure for the determination of calcium in biological specimens. Ann. Biochem., 18, 520-531.

Goldberg, D. P. (1968). A one year survey of the prevalence of psychiatric illness in patients with disease of the small intestine. Gut, 9, 725.

Gregerson, G. (1964). Motor-nerve function and duration of diabetes. Lancet, 2, 733.

Green, P. A., and Wollaeger, E. E. (1960). The clinical behaviour of sprue in the United States. Gastroenterology, 38, 399. 418.

Hall, W. H. (1968). Proximal muscle atrophy in adult celiac disease. Amer. J. dig. Dis., 13, 697-704.

Preswick, G., and Jeremy, D. (1964). Subclinical polyneuropathy in patients with renal insufficiency. Lancet, 2, 731-732.
Raskin, N. H., and Fishman, R. A. (1965). Pyridoxine-deficiency neuropathy due to hydralazine. New Engl. J. Med., 2, $1182-1185$.

Research Committee of the College of General Practitioners (1960). A survey of the epilepsies in general practice. Brit. med. J., 2, 416-422.

Sheldon, W. (1959). Celiac disease. Pediatrics, 23, 132-145.

Snyderman, S. W., Carretero, R., and Holt, L. E. (1953). Pyrid- $\Rightarrow$ oxine deficiency in the human being. Fed. Proc., 9, 371-372.

Spencer, W. (1957). Neurological manifestations in the malabsorption syndrome. In Malabsorption Syndromes, edited by D. Adlersberg, pp. 155-171. Grune and Stratton, New York.

Thomas, P. K., Sears, T. A., and Gilliatt, R. W. (1959). The range $\frac{\vec{\Phi}}{\overparen{ }}$ of conduction velocity in normal nerve fibres to the small $\mathrm{a}$ muscles of the hand and foot. J. Neurol. Neurosurg. D) Psychiat., 22, 175-181.

Watts, C. A. H. (1966). Depressive Disorders in the Community. John Wright and Sons, Bristol. 